\title{
Motivation Measurement Model to Learn Basic Buliding Construction and Survey Engineering using Confirmatory Factor Analysis
}

\author{
Evany Iqrammah ${ }^{1, a^{*}}$ and Tri Rijanto ${ }^{1, b}$ \\ 1Department of Technology and Vocational Education, Postgraduate, Surabaya State University, Surabaya, 60213, Indonesia \\ a evany.17070895010@mhs.unesa.ac.id; b tririjanto@unesaac.id \\ *Corresponding Author \\ Whatsapp number [082231055070]
}

How to Cite : Iqrammah, E., Rijanto, T. (2019). Motivation Measurement model to Learn Basic Buliding Construction and Survey Engineering using Confirmatory Factor Analysis. International Journal for Educational and Vocational Studies, 1 (7), 750-753

\section{ARTICLE HISTORY}

Received: 5 August 2019

Revised: 13 September 2019

Accepted: 10 October 2019

\section{KEYWORDS}

Learning Motivation; Basic Building Construction; Survey Engineering; Factor Analysis;

\section{ABSTRACT}

The purpose of this study was to produce an instrument of learning motivation in the subject of Basic Building Construction and Survey Engineering (DKBT) using factor analysis.Conceptually, the learning motivation instrument developed has two factors, specifically intrinsic and extrinsic. The subjects of the research were the 11 th grade students of SMKN 3 Jombang second semester 2018/2019 totaling 62 people. Data were analyzed using SPSS 24, including instrument reliability indicators (Cronbach Alpha), Kaiser-Meyer-Olkin (KMO), percentage of construction variance, and item validity (loading factor). The results showed that the Cronbach Alpha value in the classification was higher than 0.70 that was 0.93 , the KMO price was 0.681 , the construction variance percentage was $68.39 \%$, and the factor load was all items $\geq 0.3$. Thus the measurement model is suitable for measuring the learning motivation of DKBT students in the Modeling Design and Building Information.

\section{INTRODUCTION}

Armstrong (2008) has been distinguishes about motive and motivation. The meaning of motive in generally is interpreted as a tendency of a person. It is seen as still potential. Actualization of motives is called motivation which is generally manifested in real life. Bigge \& Hunt (1980); Siagian (2004), motivation is an impulse of curiosity that causes someone to make an effort or achieve their desires. Nolker \& Schoenfelft (1983) defines motivation as something that drives of behavior. Wexley (1984) says that motivation is a process that causes a person's behavior to be stronger and more directed at something that is being done. McDonald opinion about motivation is a energy of change in the people who is characterized by the emergence of affective, and reactions to achieve goals, as well as encouragement from within oneself and this impulse is a driving force (Hamalik, 2005; Lusiana et al., 2019). Armstrong (2008) defines motivation as something that makes people act or behave in certain ways. So, motivation is encouragement, something that moves a person to act or behave to achieve his goals or desires.
This is an open access article under the CC-BY-SA license.

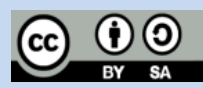


While extrinsic motivation is the desire to do something because of external rewards or avoidance of punishment.

The characteristic of extrinsic motivation in learning activities at school are started of learning activities or continuing based on needs, and encouragement that are not absolutely related to learning activities themselves (Winkel, 2009). Someone with extrinsic motivation is not too interested in the activity but only cares about what can be obtained (profits) from the activity (Woolfolk, 2006). According to Winkel, extrinsic motivation can be classified (1) learning to avoid of punishment, (2) learning to get reward, (3) learning to increase social prestige, (4) learning to get praise from important people, and (5) learning to demands of the position that you want to hold or to promotion qualify. For students who have reached secondary level, extrinsic motivation can be more dominant than before, because at this stage of development students realize the importance of learning for their own development and progress.

According to McClelland et al., (1987) motivational indicators are: (1) full of spirit to achieving success, (2) responsibility, (3) doing challenging tasks; (4) have self-confidence, (5) show the efort and and diligent in achieving goals, (7) superior desire from the others, and (8) creative and always determine realistic goals. Sadiman, et al. argues (2012) motivational indicators consist of: (1) persevering in facing tasks, (2) resilient in facing difficulties, (3) showing interest in various problems; (4) prefers to work independently, (5) gets tired of routine tasks, and (6) can defend opinions.

Curriculum 2013 (K-13) for Vocational High School, Field of Technology and Engineering, Construction and Property Engineering Skills Program, Building Modeling and Information Design Skills Competencies, subjects Building Construction Basics and Survey Engineering are basic subjects expertise program (C2) (Kemendikbud, 2017). It means that must be mastered basic subject, before studying subjects in the expertise competency group (C3). So, the subject of Building Construction Basics and Survey Engineering has an important position as a basic subject in the Construction and Property Engineering expertise program.

\section{METHODS}

This research was conducted at the State Vocational High School 3 in Jombang, East Java, Indonesia. The research subjects of class XI are 62 people. The research time is second semester 2018/2019. The instrument of learning motivation towards the subject of Modeling Design and Building Information (DPIB) was developed through the definition of constructs of learning motivation in DPIB subjects using the Liker scale with four choices, namely strongly agree, agree, disagree, and disagree. Learning motivation factors consist of two factors namely intrinsic and extrinsic factors. Data were analyzed using SPSS 24 and AMOS Conceptual framework of learning motivation instrument in DPIB subjects can be seen in Figure 1.

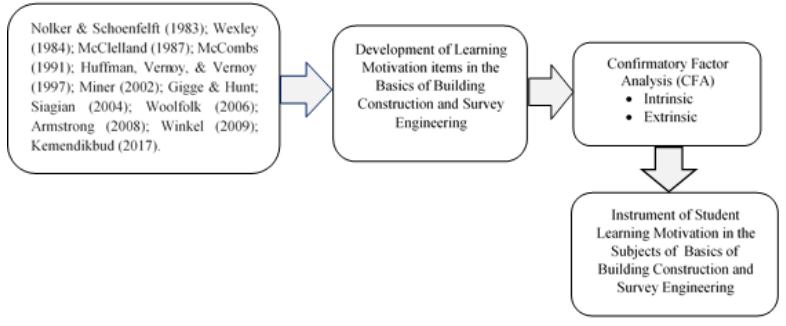

Figure. 1. Conseptual Framework

In this study the instrument reliability test was conducted on all attributes to assess the internal consistency of the variables. According to Babbie (1992), the Cronbach Alfa value is classified based on the reliability index, which is 0.90-1.00 very high, 0.70-0.89 high, 0.30-0.69 moderate, and 0.00-0, 30 low. Then the data is evaluated to find out the unidimensionality of items and factors through Confirmatory Factor Analysis (CFA) using the SPSS 24 program (Arbuckle \& Wothke, 1999). The Kaiser-Meyer-Olkin (KMO) value according to Kim \& Muller (1978) must be greater than 0.5 or the cumulative percentage of the skonstruct variant $>50 \%$ as well as the loading factor $\geq 0.3$.

\section{RESULTS AND DISCUSSION}

\subsection{Reliability}

Reliability instrument of learning motivation using internal criteria, namely internal consistency. Based on the type of data that is non-dichotomy, the instrument reliability testing uses the Alpha Cronbach reliability formula. Because it uses internal criteria, instrument reliability testing is performed for each factor. Calculation of the combined reliability of all factors according to Nunnally (1978) used the combined reliability formula based on a linear combination system.

The analysis results obtained an Alpha value of 0.93 above the acceptable threshold of 0.70 as suggested by Babbie (1992). According to Babbie (1992) the Cronbach Alpha value is classified based on the classification of the reliability index where $0.90-1.00$ is very high, $0.70-0.89$ is high, 0.30-0.69 is moderate, and 0.00 is 0.30 low. Analysis shows the Cronbach Alpha value of 0.93 above 0.70 and included in the classification is very high. Thus the learning motivation instrument has a very high reliability to measure students' motivation to study in the subject of Basic Building Construction and Survey Engineering (DKBT).

\subsection{Item Validity and Load Factor}

To interpret to determine whether an item is fall or not, then it is taken through the following three steps. First, by looking at relation or correlations between grains that are relevant to each other in the formation of factors through product moment correlation. Second, extraction to arrange the initial factors using principal component 
analysis. Third, rotating the factors to be interpreted using orthogonal methods with the varimax system. The results of the rotation of the factor matrix along with the

Table 1. Test Results For Item Validity and Factor Loadings

\begin{tabular}{|c|c|c|c|c|}
\hline Factor & Indicators & Item Numbers & Load Factors & Explanation \\
\hline \multirow[t]{9}{*}{ Instrinsik } & Have a high enthusiasm for success in DKBT subjects & $\mathrm{X} 1$ & 0.706 & Valid \\
\hline & The desire of students to explore DKBT subjects & $\mathrm{X} 2$ & 0.717 & Valid \\
\hline & Have responsibility for the tasks given by subject teachers of DKBT & $\mathrm{X3}$ & 0.819 & Valid \\
\hline & Carry out tasks with tenacity when facing difficult DKBT subjects & $\mathrm{X} 4$ & 0.763 & Valid \\
\hline & Have confidence in participating in learning subject DKBT & $\mathrm{X} 5$ & 0.740 & Valid \\
\hline & Independently acted in following the DKBT subject & $\mathrm{X} 6$ & 0.946 & Valid \\
\hline & Demonstrating hard and diligent efforts in following the DKBT subject & X9 & 0.913 & Valid \\
\hline & Courage to face failure & $\mathrm{X} 7$ & 0.650 & Valid \\
\hline & Want to be superior in following DKBT subjects & $\mathrm{X} 8$ & 0.879 & Valid \\
\hline \multirow[t]{8}{*}{ Ektrinsik } & Encouragement from the teacher for the spirit of learning DKBT subject & $\mathrm{X} 10$ & 0.562 & Valid \\
\hline & Learning models and media used by teachers when delivering DKBT learning materials & $\mathrm{X} 11$ & 0.840 & Valid \\
\hline & Encouragement from parents and family to attend DKBT subjects & $\mathrm{X} 12$ & 0.847 & Valid \\
\hline & Collaboration between friends when completing group assignments on DKBT subjects & $\mathrm{X} 13$ & 0.619 & Valid \\
\hline & Complete infrastructure of the school & $\mathrm{X} 14$ & 0.655 & Valid \\
\hline & Competency Test Competencies in the field of Modeling Design and Building Information & $\mathrm{X} 16$ & 0.586 & Valid \\
\hline & The suitability of the subject matter of DKBT with the implementation in the Prakerin field & & & \\
\hline & & X15 & 0.896 & Valid \\
\hline
\end{tabular}

\subsection{Model Relations and item factors}

Based on the factor analysis on the matrix component shows that of the 20 items as many as 4 items have a factor load of $\leq 0.30$, so the items are declared fall. Valid items are 16 items. Furthermore, a factor analysis is carried out again by not involving invalid items. From the matrix component, it can be arranged a model of the relationship of items with factors as shown in Figure 2.

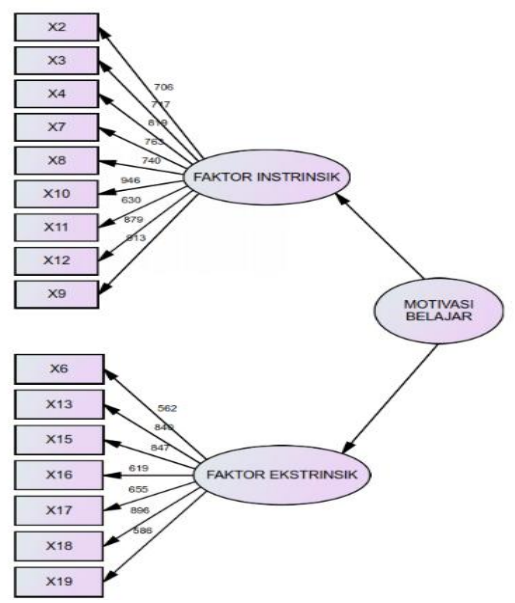

Figure 2. Model Relationships of Items and Factors

\section{CONCLUSION}

The theoretical concept of learning motivation instruments for DKBT subjects consists of two factors, namely intrinsic and extrinsic. The fit-model indicator is characterized by reliability (Cronbach Alpha), Kaiser-Meyer-Olkin (KMO), percentage of construction variance, and item validity (loading factor). The analysis interpretation, labeling, and meaning of the factors of the learning motivation instrument can be seen in Table 1. shows Cronbach Alpha value of $0.93, \mathrm{KMO}$ value of 0.681 , percentage value of construction variance of $68.39 \%$, and item factor load ( 16 valid items) $\geq 0.3$. Thereby, fit-model theoretical model so that the DKBT learning motivation instrument can be used.

\section{REFERENCES}

Artiningsih, A., Riyanto, Y., \& Harmanto, H. (2019). Influence of Learning Model Type Cooperative Scramble with Picture Media on Motivation and Student's Learning Outcomes of IPS Class 2 SDN 2 Tropodo. International Journal for Educational and Vocational Studies, 1(2). 81-85.

Armstrong, Michael. (2008). How to manage people. London, GBR: Kogan Page Ltd.

Babbie, Earl R. (1992). The practice of social research. Belmont, California: Wadsworth Pub. Co.

Hamalik, Oemar. (2005). Pengembangan sumber daya manusia manajemen pelatihan ketenagakerjaan pendekatan terpadu. Jakarta: Bumi Aksara.

Huffman, Vernoy, and Vernoy. (1997). Psychology in action, $2^{\text {nd }}$ Edition. New York: Wiley and Sons.

Kemendikbud. (2017). Keputusan Direktur Jenderal Pendidikan Dasar dan Menengah Nomor 130/D/KEP/KR/201 tanggal 10 Pebruari 2017 tentang Struktur Kurikulum Pendidikan Menengah Kejuruan.

Lusiana, L., Rukun, K., \& Yahya, Y. (2019). Contribution of Certification and School Climate Allowances to The Motivation of Teacher Work in the Middle School 
District of Kinali, West Pasaman Regency. International Journal for Educational and Vocational Studies, 1(5). 509-513.

Mada, R. D., \& Anharudin, A. (2019). How Online Learning Evaluation (Kahoot) Affecting Students' Achievement and Motivation (Case Study on it Students). International Journal for Educational and Vocational Studies, 1(5), 422-427.

McClelland, David C. (1987). Human motivation. New York: Press Syndicate of the University of Cambridge.

McCombs, S.A., \& Kirkpatrick, J.M. (2016). Impact of pedagogical approaches on cognitive complexity and motivation to learn: Comparing nursing and engineering undergraduate students. Nursing Outlook, 64(1), 37-48.

https://doi.org/https: / /doi.org/10.1016/j.outlook.20 15.10.006

Miner, John B. (2002). Organizational Behavior: Foundations, Theories, and Analyses. Oxford: Oxford University Press.

Nunnally, J. C. (1978). Psychometric theory (2 $2^{\text {nd }}$ Edition). New York, NY: McGraw-Hill Book Company.

Nolker, Helmut \& Schoenfeldt, Eberhard. (1983). Pendidikan kejuruan (Alih Bahasa Agus Setiadi). Jakarta: PT. Gramedia.

Sadiman, dkk. (2012). Media Pendidikan. Jakarta: Rajagrafindo Persada.

Siagian, Sondang P. (2002). Kepemimpinan Organisasi \& Perilaku Administrasi. Jakarta: Penerbit Gunung Agung.

Wexley, Kenneth N. (1984). Organizational behavior personal psychology. Homewood, Illinois: Richard D. Irwin, Inc.

Widarjono, Agus. (2010). Analisis Statistika Multivariat Terapan. Edisi pertama. Yogyakarta: UPP STIM YKPN.

Winkel, W. S. (2009). Psikologi Belajar. Yogyakarta: Media Abadi. 